\title{
ASSESSMENT OF ENVIRONMENTAL DAMAGES IN CASE OF FLOOD IN BODVA RIVER BASIN, SLOVAKIA
}

\author{
MARTINA ZELEŇÁKOVÁ ${ }^{1}$, PETER BLIŠŤAN ${ }^{2}$, IBRAHIM ALKHALAF ${ }^{1}$, \\ LENKA GAŇOVÁ ${ }^{3} \&$ LENKA ZVIJÁKOVÁ 4 \\ ${ }^{1}$ Institute of Environmental Engineering, Technical University of Košice, Slovakia. \\ ${ }^{2}$ Institute of Geodesy, Cartography and Geographical Information Systems, \\ Technical University of Košice, Slovakia. \\ ${ }^{3}$ Slovak Water Management Enterprise, s.c., branch office Košice, Slovakia. \\ ${ }^{4}$ Eurodotacie, Erste Group Bank, Košice, Slovakia.
}

\begin{abstract}
Environmental and natural values may be affected by floods, despite the fact that floods are to some extent a natural phenomenon. Effects of floods can take many forms, physical damage, injury, death, environmental pollution, etc. A significant part of the environmental damage, the leakage of harmful substances that may be in various forms, affects ecosystems long after the flood. In the case of flood, the main damages on the environment may occur as a consequence of accidents at sources of pollution. The issue of pollution sources is a key area of environmental protection. While pollution from point sources can be disposed by suitable technology, for diffuse pollution it is essential to propose preventive measures that create conditions to prevent contamination. The purpose of this paper is to assess the impacts of the sources of pollution during floods in the catchment of Bodva River, situated in the south-east part of the Slovak Republic. We stated the classification of sources of pollution according to the degree of danger for environment and quantification of their impact on the environment by weighting method. Each source of pollution was divided into categories according to different criteria based on literature studying, consultation and experiences. The results from evaluation proved no significant environmental pollution of the studied catchment in the case of flood. Anyway in the evaluated area, the Bodva River basin, there is a need to ensure effective flood control measures not only for protection but also in terms of economic, social and environmental issues. Evidence that flood protection and prevention are justified and must be one of the most important parts of spatial planning is critical to recurrent flood damage.
\end{abstract}

Keywords: Bodva basin, flood risk, sources of pollution.

\section{INTRODUCTION}

The aim of flood risk management is the proposal of flood protection measures. The main objective of management as well as the entire management cycle is regulated by the Directive of the European Parliament and of the Council 2007/60/EC on the assessment and management of flood risks. The aim of this directive is to reduce and control the adverse consequences on human health, the environment, cultural heritage and economic activity associated with floods. The objective of the paper is to propose a methodology which could be used for preliminary flood risk assessment of floods.

For achieving the goals of directive 2007/60/EC [1], which is implemented in the legislative of the Slovak Republic by Act no. 7/2010 on the flood protection [2], the obligation is placed on all member states to work up a preliminary flood risk assessment, which was 
completed in December 2011; to prepare maps of flood hazard areas and maps of flood risk, which were completed in 2013; and to work up plans for management of flood risk, which were completed in 2015. Subsequently, the individual steps must then be updated every 6 years.

In the last decade, Slovakia is being increasingly affected by floods [3, 4]. Floods constantly point to the fact that the society is very vulnerable, but it has been proved that flood-related problems could be solved through planning studies and detailed projects about flood prone areas [5-8]. Floods are so dangerous for the environment mainly when sources of pollution are situated in the flooded area. A pollution that results from a human activity may cause deterioration in the status of a water body. In most cases, such pollution relates to the addition, or release, of substances into the environment. This can be the leaching of a waste product, but may also be the side-effect or by-product of some other activity, such as the leaching of nutrients from agricultural land. A pollution pressure may also be caused by an action such as a change in land use, for example sediment fluxes are modified by urbanization, forestry, and a change between winter and spring planting of crops. The most usual categorization of pollution pressures is to distinguish between diffuse and point sources (Table 1). However, the distinction between point and diffuse sources is not always clear and may again relate to spatial scale according to European Commission [9]. For example, areas of contaminated land might be considered as either diffuse or point sources of pollution.

The assessment of whether risk on a water body is significant must be based on knowledge of the pollution within the catchment area, together with some form of conceptual understanding, of water flow, chemical transfers, and biological functioning of the water body within the catchment system [9]. Finally, flood risk analysis provides a rational basis for prioritizing resources and management actions mainly in the flood vulnerable areas. Risk analysis can take many forms, from informal methods of risk ranking and risk matrices to fully quantified analysis [10].

The paper studies the impact of the sources of pollution and flooding water on the environment. Environmental impact study in Bodva river basin includes the natural condition identification as well as human activity identification which may cause environmental damages in case of floods in the river basin.

\section{STUDY AREA}

Bodva river basin (Fig. 1) is situated in the southwestern part of the Kosice region. The river Bodva rises in the mountains Volovske hills, on the north eastern slope of the hill Osadník (1186 m asl.). The length of its flow in Slovakia is $48.4 \mathrm{~km}$. Within the territory of Hungary it flows into the Slaná River. A larger right-hand side inflowing tributary of the Bodva is the Turňa and on the left-hand side the Ida. The whole area of Kosice region belongs into the zones of Inner Western Carpathians (Fig. 2). Geological structure of the area forms the hydrogeological conditions of the sub-basin Bodva. Older Paleozoic rocks whose original character before metamorphosis was volcanic with intergranular permeability are characteristic by fissure permeability. There is a predominance of heavy loamy soils that occupy contiguous area of Košice basin. Sandy-loam soils occupy forests in the mountains Volovske hills and partially Slovak Karst MoE \& SWME [11].

The orographic condition range from $168 \mathrm{~m}$ asl. (Host'ovce) to $1186 \mathrm{~m}$ asl (Osadník). Height and slope conditions affect climatic conditions, especially the size and distribution of rainfall, and thus on the overall water balance and runoff regime. Sub-basin Bodva, regarding the complex orographic ratio, ranges into several climatic zones. South and east part - the 


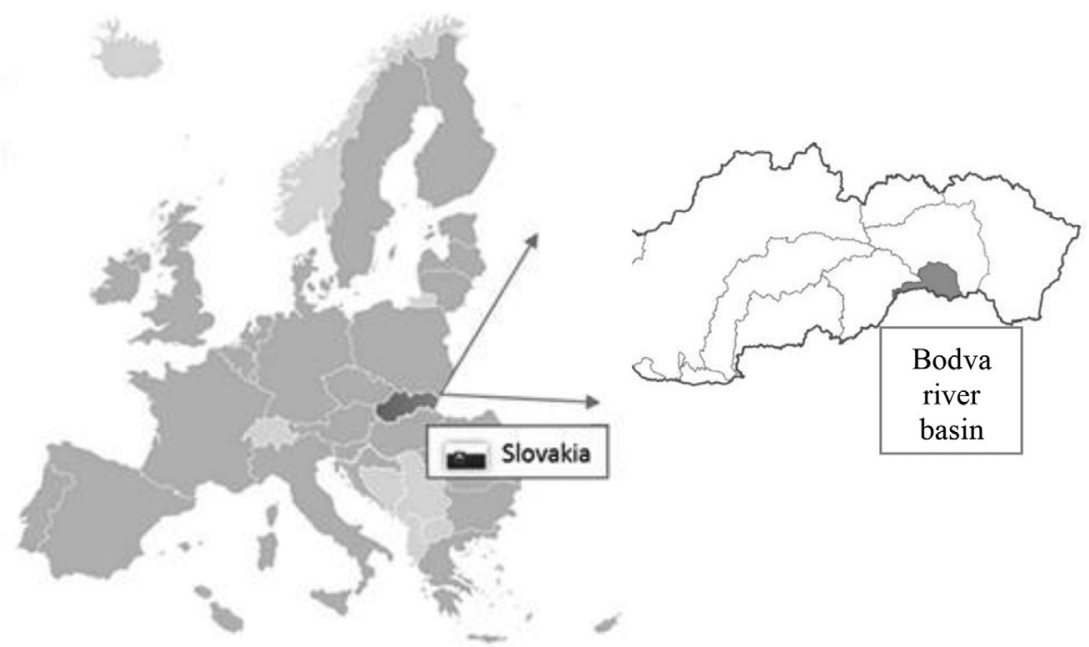

Figure 1: Localization of Bodva river basin in Slovakia.

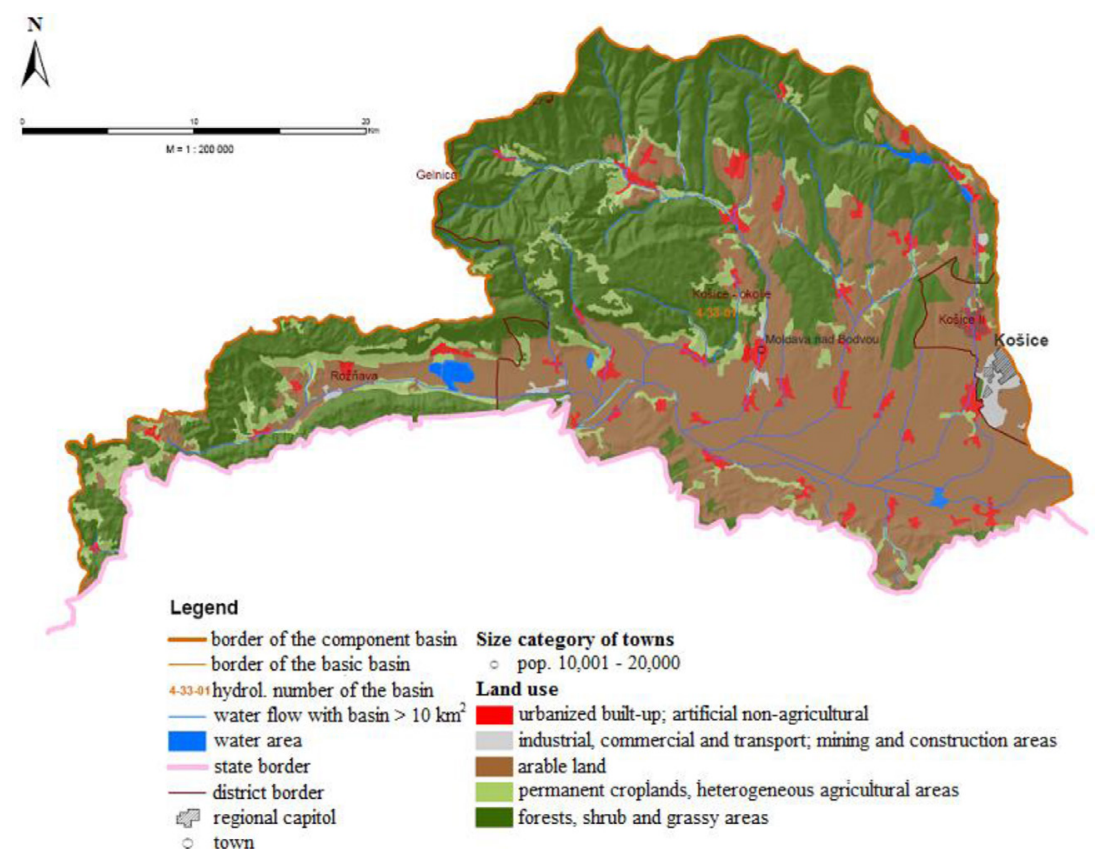

Figure 2: Characteristics of Bodva river basin in Slovakia.

largest part of the basin belongs to warm climate, which is and slightly damp with cold winters. Long-term average annual air temperatures range from $5^{\circ} \mathrm{C}$ to $8^{\circ} \mathrm{C}$. Long-term average annual precipitations in the basin range from 600 to $1000 \mathrm{~mm}$. The land use is as follows: artificial surfaces $-4.7 \%$; agricultural areas $-48.1 \%$; forested and semi-natural areas $46.6 \%$; wetland areas $-0.1 \%$; waters $-0.5 \%$, according to Zeleňáková [12]. 
The first mention of floods in Bodva river basin with serious consequences on the population which occurred in chronicles is the flood of 1813, when flooding affected the town of Moldava nad Bodvou. The next large flood is recorded in July of 1845, but from sources' descriptions its course and consequences are only known in the neighboring basins (the Hnilec and Slaná), and it probably also affected the component basin of the Bodva. Long-lasting and exceptionally profuse rains caused flooding situations in the Bodva basin also in the years 1973, 1974, 1989, 1995 and 1996. In 1997 and 1998, no water stages higher than the water stage designated for first degree of flood activity were recorded in the hydro prognosis stations of the SHMÚ in the component of the Bodva basin. In 1999 in the component basin of Bodva, 10 days occurred in which a water stage designated for degrees of flood activities was reached or surpassed in the hydroprognosis stations of the SHMÚ. And the year 2005 belonged among years with flood activities. In the Bodva basin at the water measuring station at Turňa nad Bodvou with a flow of $Q_{\max }=43.4 \mathrm{~m}^{3} \mathrm{~s}^{-1}$, the level of the water rose to a water stage level of $293 \mathrm{~cm}$, which corresponds to the level designated for the second degree of flood activity. And even 2006 did not pass without flood events, which occurred especially in March, April, May and June. Water stages corresponding with the degree of flood activities were achieved or surpassed in nearly all flows in the basin. In 2009, the first flood situation occurred in the final third of January, which was the warmest and at the same time when the highest total rainfall on the entire territory occurred. The next flood situation in the Bodva basin occurred at the end of 2009, in the second half of December. The year 2010 was from the viewpoint of rainfall exceptionally above average in the Bodva basin. The first flood of 2010 in the component basin of the Bodva occurred in the first half of January. In April, a second flood occurred which resulted from long-lasting and substantial rainfall which fell over the course of 3 days. These rains caused a rapid and significant rise in water levels. The floods in May and June 2010 were exceptional from the viewpoint of time and spatial distribution in the Bodva basin. In nearly all water measuring stations water stages designated as third degree flood activities were surpassed. Further above-average rainfall occurred in November. Precipitation activities continued even into the early part of December and the larger part of the precipitation was repeatedly in the form of rainfall. In the scope of a flood risk assessment in the Bodva river basin, five areas $(17.2 \mathrm{~km}$ - the length of river sections in flood risk) were identified with the occurrence of significant flood risk, according to MoE \& SWME [11], from this (Fig. 3):

- Areas with the existing potential for significant flood risk $(6.7 \mathrm{~km})$

- Areas with probable potential for significant flood risk $(10.5 \mathrm{~km})$.

The present state of flood protection not only in the component basin of the Bodva but also throughout Slovakia is the result of long-term development. Agricultural development and the building of industry which was connected primarily with the development of towns has forced the construction of technical preventive measures for flood protection in the landscape and along watercourses. Present flood protection infrastructure in the component basin of the Bodva takes into consideration especially the alteration of watercourses, protective levees and reservoirs. No dry basins are located in the area.

In the component basin of the Bodva, there are three reservoirs, the function of which is to change the time progression and size of water flow rates or to hold water so that it can be used most usefully and not cause any damage. With the building of protective levees or anti-flood lines, the increasing capacity of the watercourse for protection of the territory from flooding 


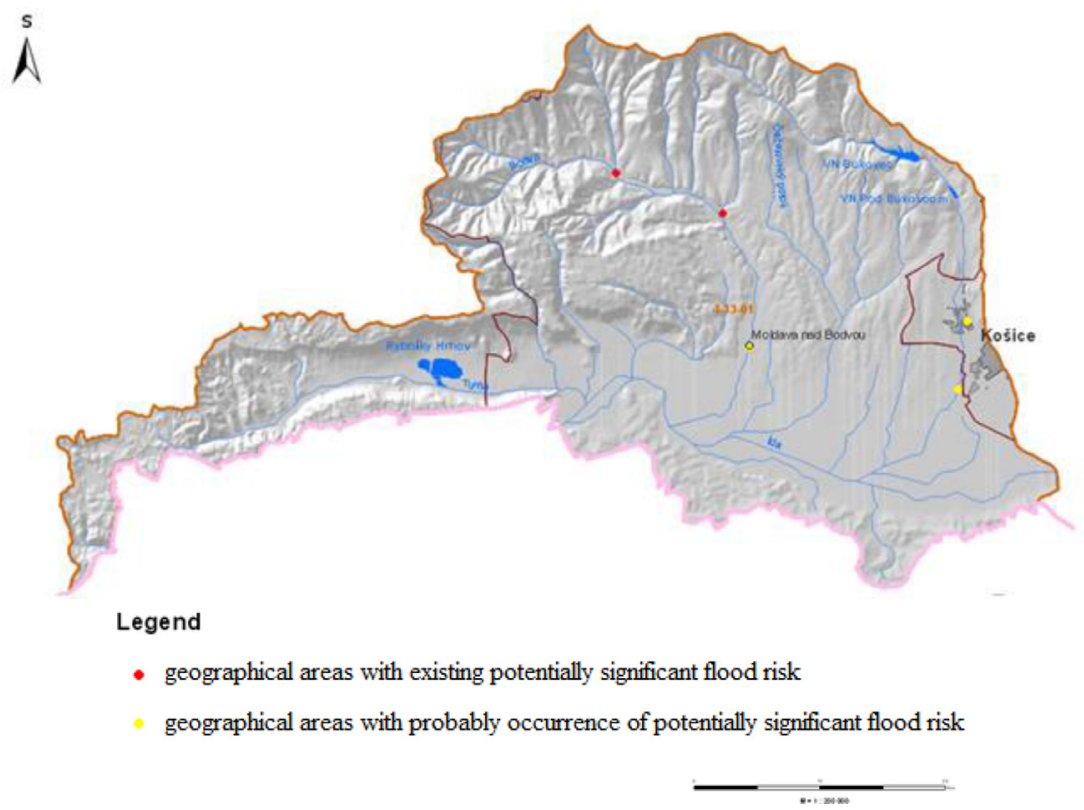

Figure 3: Geographical areas with potentially significant flood risk in Bodva river basin.

with smaller flow rates or equal to the proposed flow rate follows. The goal of modification of watercourses is to create favorable conditions for their water management use and to remove the consequences of their damaging effect. At present, several alterations of watercourses are being carried out in the component basin of the Bodva and four protective levees are being built.

A preliminary flood risk assessment from flash floods, that is the assessment of an area with this flood risk, requires a quantity of data foundations of a corresponding range.

The methods which are used in the contribution emerge from practical experience as well as from knowledge obtained from the available literature and consultations with experts dealing with the given problem in practice. The foundations of flood risk assessment are hypotheses on the impact of physio-geographical attributes of basins on the origin of floods. The conceptual framework for flood risk assessment of flash floods comes from the definition of a multidimensional conception of flood risk, and a process approach is used.

\section{RESULTS AND DISCUSSION}

The principle philosophy of assessing damage to the environment comes from the fact that all three environmental elements evaluated (protected biotopes, water and soil) can be damaged by the impact of a whole range of floating hazardous substances from potential sources of contamination. Attention is therefore devoted to the quality of the water, exactly to the evaluation of sources of pollution situated in flooded area, which can cause the potential environmental damages in case of floods.

Potential sources of water contamination are all activities in the catchment, all contaminated sites and landfills, industrial activities, agricultural activities, and other activities. 
Point sources of pollution, that is, potentially, were also found through three dedicated databases, according to Water Research Institute [13] and Slovak Environment Agency [14]:

- KV-ENVIRO, which contains more than 13,004 potential point sources of pollution. The basis of this database is a database GeoEnviron, which contains 9177 potential point sources of pollution. These are 2279 sites, 6938 landfills and other sources of pollution.

- Register of contaminated sites (REZ), which is part of the Information System of Slovak Environment Agency, was built under the project Systematic identification of contaminated sites in the Slovak Republic. It contains 1936 sites, which are divided into three parts: likely environmental burdens (Part A) - 902 sites, environmental burdens (Part B) - 281 sites, rehabilitated and reclaimed environmental burdens (Part C) - 753 sites.

- Database: Integrated monitoring of pollution sources, which contains sources of pollution of hazardous substances, which monitor their impact on groundwater. This database currently contains more than 310 sources of pollution, mainly landfills.

Flooding of the above mentioned sources of pollution as well as diffuse sources of pollution may leak out pollutants and thus deteriorate the quality of surface water, groundwater, and soils, which can lead to environmental disasters, such as damage of habitats, fauna and flora as well as diseases and epidemics occurrence.

The starting point for assigning a category of the consequence is categorization of potential sources of contamination influencing the quality of water (Table 1).

At present, no complete register of sources of contamination exists in the Slovak Republic; therefore, for the needs of this paper one of our own designs was created. The individual sources of contamination are divided into two main categories: point and diffuse sources of contamination. Table 1 presents the divisions of the individual sources of contamination, their point classification and the weight indicating the importance of the component categories. When assigning points an inverse order is used; thus, the value 5 represents the greatest threat of contamination in the case of flooding. The individual weights of the component categories, which are standardized such that their sum is equal to one, are set in this same way. The individual points are set on the basis of a professional judgement.

The actual sources of pollution in the studied area, situated in the flooded area are marked in bold in Table 1. It is resulted as follows:

- Agricultural area $\left(1,544,701 \mathrm{~m}^{2}\right)$ contains $49.83 \%$ from whole the flooded area $\left(3,099,950 \mathrm{~m}^{2}\right)$ (by $Q_{100}$ ) - data from GIS (done by authors);

- Percentage of population without sewerage is $24.7 \%$, as from 29,390 of equivalent inhabitants $46.6 \%$ is connected to sewerage systems and $28.7 \%$ has individual systems of wastewater treatment - based on data from Medzev City [15];

- Environmental burden - there is one confirmed burden in the study area 'Strojsmalt', storehouse of heavy oils and fuels, in Medzev (Fig. 4) - according to the Register of contaminated sites;

The flooding of these objects can lead to leakage and the washing away of contaminating substances and thus to worsening the quality of surface and underground water and soils, which can lead to ecological catastrophes, such as damage to biotopes, the killing of fauna and flora as well as epidemics. Very serious damage of a long-term character is related to underground aquifers, which are used as sources of drinking water. The total consequence 
Table 1: Classification of sources of pollution.

\begin{tabular}{|c|c|c|c|c|}
\hline $\begin{array}{l}\text { Source of } \\
\text { pollution }\end{array}$ & Characteristic & Criteria & $\begin{array}{c}\text { Point } \\
\text { classification }\end{array}$ & Weight \\
\hline \multicolumn{5}{|c|}{ Point sources of pollution } \\
\hline \multirow{3}{*}{$\begin{array}{l}\text { Industrial } \\
\text { enterprises }\end{array}$} & \multirow{3}{*}{$\begin{array}{l}\text { Category of } \\
\text { enterprise }\end{array}$} & unclassified & \multirow[t]{3}{*}{5} & 0.2 \\
\hline & & A & & 0.3 \\
\hline & & $\mathrm{B}$ & & 0.5 \\
\hline \multirow{4}{*}{$\begin{array}{l}\text { Sewage treatment } \\
\text { plants }\end{array}$} & \multirow{4}{*}{$\begin{array}{l}\text { Number of } \\
\text { equivalent } \\
\text { inhabitants }\end{array}$} & $<2,000$ & \multirow[t]{4}{*}{4} & 0.14 \\
\hline & & $2,000-10,000$ & & 0.21 \\
\hline & & $10,000-100,000$ & & 0.29 \\
\hline & & 100,000 and more & & 0.38 \\
\hline Petrol stations & - & - & 4 & 1 \\
\hline \multicolumn{5}{|c|}{ Diffuse sources of pollution } \\
\hline \multirow[t]{3}{*}{ Landfills } & \multirow{3}{*}{$\begin{array}{l}\text { Type of landfill } \\
\text { for }\end{array}$} & inert waste & \multirow[t]{3}{*}{5} & 0.12 \\
\hline & & non-hazardous waste & & 0.29 \\
\hline & & hazardous waste & & 0.59 \\
\hline Impoundments & - & - & 3 & 1 \\
\hline \multirow[t]{2}{*}{ Mine activities } & \multirow[t]{2}{*}{ Type } & underground & \multirow[t]{2}{*}{2} & 0.4 \\
\hline & & surface & & 0.6 \\
\hline \multirow{3}{*}{$\begin{array}{l}\text { Population in } \\
\text { urban areas }\end{array}$} & \multirow{3}{*}{$\begin{array}{l}\text { Percentage } \\
\text { of population } \\
\text { without sewerage }\end{array}$} & 0-40 & \multirow[t]{3}{*}{3} & 0.12 \\
\hline & & $40-60$ & & 0.29 \\
\hline & & $60-100$ & & 0.59 \\
\hline \multirow{3}{*}{$\begin{array}{l}\text { Agricultural } \\
\text { areas }\end{array}$} & \multirow{3}{*}{$\begin{array}{l}\text { Percentage of } \\
\text { arable land in the } \\
\text { area }\end{array}$} & $0-40$ & \multirow[t]{3}{*}{3} & 0.29 \\
\hline & & $40-60$ & & 0.59 \\
\hline & & $60-100$ & & 0.12 \\
\hline \multirow{3}{*}{$\begin{array}{l}\text { Environmental } \\
\text { burden }\end{array}$} & \multirow[t]{3}{*}{-} & is reclaimed & \multirow[t]{3}{*}{4} & 0.12 \\
\hline & & is likely & & 0.29 \\
\hline & & is confirmed & & 0.59 \\
\hline
\end{tabular}

(Table 2) is calculated as the sum of the assigned points to the individual sources of contamination located in the flooded area for the given $Q_{\mathrm{N}}$ (probability of flood occurring) multiplied by the relevant weight, and this defines the negative impact on the environment.

The resulted Flood Environmental Impact and Risk Assessment (FEIRA) is stated as the sum of the state of the environment (EIA - environmental impact assessment), predisposition for floods and sources of pollution in the area (RA - risk analysis) and present hazard in case of flood occurrence. The philosophy of the methodology is stated in Fig. 5.

In general expression environmental impact assessment is probability $(\mathrm{P}) \mathrm{x}$ consequence (C) of adverse impacts of floods for the environment. Risk analysis is hazard $(\mathrm{H}) \mathrm{x}$ weight (W). Hazard in environment is presented by sources of pollution in the area which present a serious risk for the environment in the case of flood. All calculations are not presented in the paper because of the length of the article. All calculations are made from presented information of Bodva river basin. The resulted FEIRA is stated as the sum of the state of the 


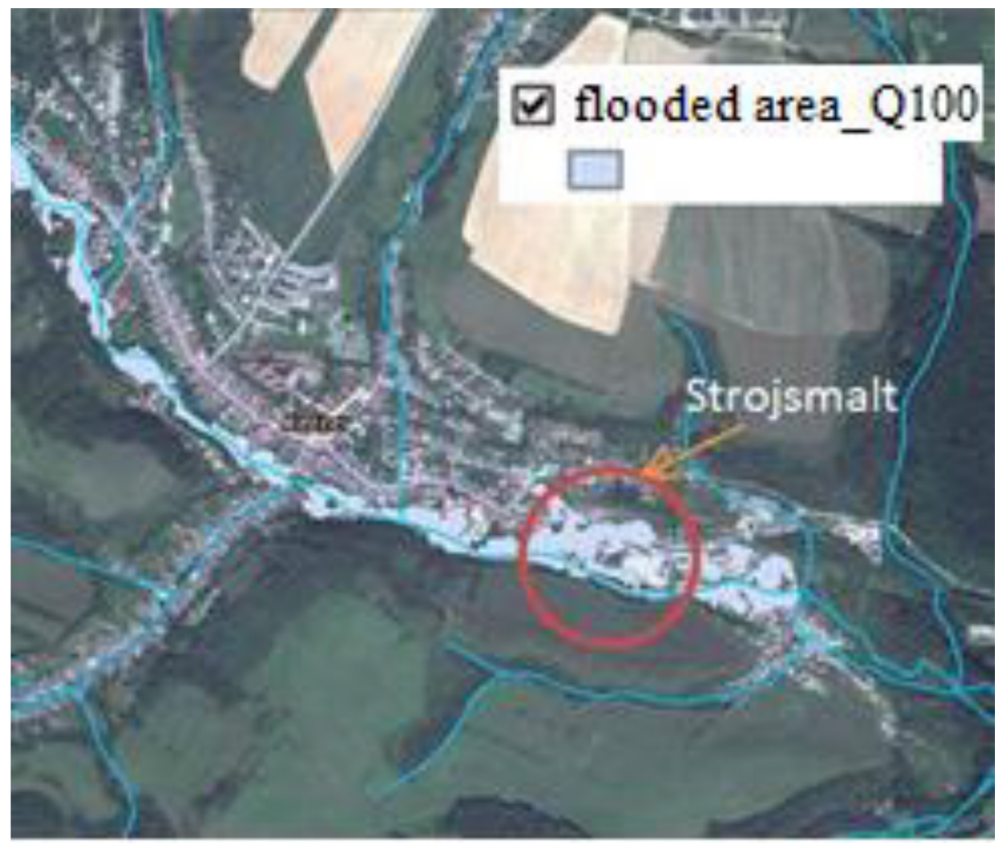

Figure 4: Strojsmalt in Medzev situated in flooded area.

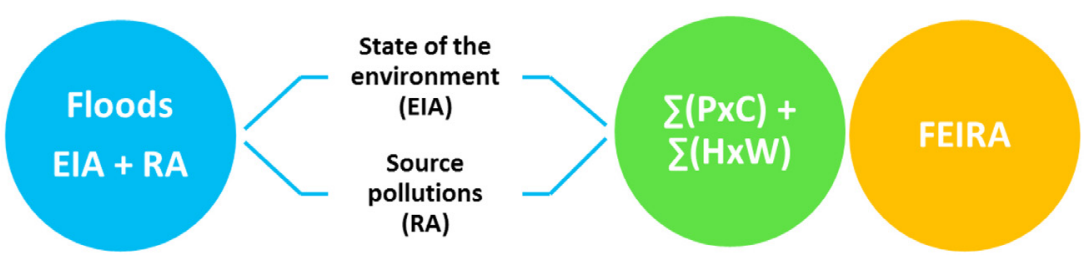

Figure 5: Methodology of FEIRA.

environment and the classification of sources of pollution by point classification. Flood risk in Bodva river basin was stated as negligible and low.

\section{CONCLUSION}

Basically, two phases are applied in this study to analyze flood vulnerability: firstly to identify the effective factors causing floods - the potential natural causes of flooding, and secondly to apply methods of MCA in GIS environment to evaluate the flood vulnerability of the area.

The flood vulnerable areas in the study area Bodva watershed were evaluated in four classes. Since the methods take into account some conditions of the region, the results can be as realistic only for this condition. When the characteristics would change, different results would be obtained. The subjective numbers in the weights and the values of the criteria can be changed according to the study area characteristics and experts' opinions. Our pilot study showed the possibility of using MCA and GIS for flood vulnerability assessment 
On the basis of the knowledge of the current state of existing modifications we propose, in the resolved area of the town of Medzev, these possible preventive flood mitigation measures:

- Removing of sediments from the riverbed and vegetation on the bank of the water flow, thus securing the flow-rate capacity of the channel of the watercourse,

- On unmodified segments of the watercourse, carry out modification, for example, reinforce the slopes of the watercourse banks,

- Possible construction of a reservoir above the town which lowers the maximum flow rate during increased water stages.

In the Bodva river basin, according to Slovak Water Management Enterprise, state enterprise Branch Office Kosice, the total vulnerability of property is 57,306,649 euro and number of inhabitants endangered by floods is 4575 . The proposed preventive measures include the following [16]: measures that slow drainage of water from the basin into waterways, increasing the retention capacity of the river basin or support the natural accumulation of water in areas of suitable territory and protecting territory against flooding by surface drainage, such as adjustments in forests, farmland modifications and adjustments to the urbanized areas,

- Measures that reduce the maximum flow of floods, such as construction, maintenance, repair and reconstruction of water works and polders

- Measures that protect the area against flooding water from a watercourse, such as the modification of water courses, construction, maintenance, repair and reconstruction of levees and flood lines along waterways

- Measures to protect the area against flooding inland waters, such as construction, maintenance, repair and reconstruction of facilities for the transfer of internal waters

- Measures to ensure the flow capacity of the watercourse bed as removing silt from the riverbed of the watercourse, and stands on the banks of the watercourse.

The proposed flood mitigation measures in Jasov (area of existing potential for significant flood risk) and Moldava nad Bodvou (area with probable potential for significant flood risk) are as follows Vágášiová [16]:

- Increasing of flow capacity by construction of riverside walls and earth dyke

- Extended riverbed, fortify river channel slopes in the local area of Budulov (part of Moldava)

- Area between the town of Moldava nad Bodvou and Jasov should be left to the natural transformation of flood waves

The total estimated costs of flood mitigation measures in Bodva river basin are 40,678,000 Euro.

\section{ACKNOWLEDGEMENT}

This paper was written thanks to support from project VEGA 1/0609/14.

\section{REFERENCES}

[1] Directive 2007/60/EC of the European Parliament and of the Council of 23 October 2007 on the assessment and management of flood risks. 
[2] Act no. 7/2010 of Slovak republic of 27 October 2004 on the flood protection.

[3] Zeleňáková, M., Preliminary flood risk assessment in the Hornád watershed. In: River Basin Management V 15, Wessex Institute of Technology: Ramla Bay Resort, Malta. Southampton, pp. 15-24, 2009. http://dx.doi.org/10.2495/rm090021

[4] Zeleňáková, M., Flood risk assessment and management in Slovakia. In: River Basin Management 6, WIT Press: Riverside, California, USA. Southampton, pp. 61-69, 2011. http://dx.doi.org/10.2495/rm110061

[5] Hanák, T. \& Korytárová, J., Risk zoning in the context of insurance: Comparison of flood, snow load, windstorm and hailstorm. Journal of Applied Engineering Science, 12, pp. 137-144, 2014.

[6] Hlavčová, K., Kohnová, S., Kubeš, R., Szolgay, J. \& Zvolenský, M., An empirical method for estimating future flood risk for flood warnings. In Hydrology and Earth System Sciences, 9(4), pp. 431-488, 2005. http://dx.doi.org/10.5194/hess-9-431-2005

[7] Korytárová, J., Šlezingr, M. \& Uhmannová, H., Determination of potential damage to representatives of real estate property in areas afflicted by flooding. Journal of Hydrology and Hydromechanics, 55, pp. 282-228, 2007.

[8] Solín, L., Spatial variability in the flood vulnerability of urban areas in the headwater basins of Slovakia. Journal of Flood Risk Management, 5(4), pp. 303-320, 2012. http://dx.doi.org/10.1111/j.1753-318X.2012.01153.x

[9] European Commission: Analysis of Pressures and Impacts [online]. Luxembourg: Office for official publications of the European communities, 2003, available at: https:// circabc.europa.eu/sd/a/7e01a7e0-9ccb-4f3d-8cecaeef1335c2f7/Guidance\%20No\%20 3\%20-\%20pressures\%20and\%20impacts\%20-\%20IMPRESS\%20(WG\%202.1).pdf

[10] Hall, J., Journal of flood risk management. Journal of Flood Risk Management, 3(1), pp. 1-2, 2010.

http://dx.doi.org/10.1111/j.1753-318X.2009.01059.x

[11] MoE (Ministry of Environment), SWME (Slovak Water Management Enterprise), Implementation of directive 2007/60/ES of 23rd October 2007 on flood risk assessment and management: Preliminary flood risk assessment in Bodrog river basin, Attachments [online]. December 2011 available at: http://www.minzp.sk/files/sekcia-vod/ bodrog-prilohy.pdf

[12] Zeleňáková, M., Assessment of flood vulnerability in Bodva catchment using multicriteria analysis and geographical information systems. In: River Basin Management WIT press: A Coruna, Spain, 8, pp. 51-59, 2015.

http://dx.doi.org/10.2495/rm150051

[13] Water research institute (WRI), Database GeoEnviron, 2008.

[14] Slovak Environmental Agency (SEA), State list of protected areas of Slovakia, 2013, available at: http://uzemia.enviroportal.sk/

[15] Medzev City, Program of the economic and social development. Socio-Economic Analysis, 2013, available at: http://www.medzev.info/mesto/legislativa/phsr

[16] Vágášiová, M., Experiences in processing of flood risk management plan in terms of Slovak Water Management Enterprise, s.e., Branch Office Košice. 2014, available at: http://www.urbiproof.info/wp-content/uploads/2014/09/08_Vagasiova.pdf 